\title{
Generation cycle closure of the spotted rose snapper, Lutjanus guttatus, in captivity
}

\author{
Cierre del ciclo generacional del pargo flamenco, Lutjanus guttatus, en cautiverio
}

\author{
Leonardo Ibarra Castro ${ }^{1}$, Luis Alvarez-Lajonchère ${ }^{2}$, Noemi García-Aguilar ${ }^{1}$, \\ María Isabel Abdo de la Parra ${ }^{1}$ and Luz Estela Rodríguez-Ibarra ${ }^{1}$
}

\author{
${ }^{1}$ Centro de Investigación en Alimentación y Desarrollo (CIAD), A. C., Unidad Mazatlán, Avenida Sábalo Cerritos S/N, \\ Mazatlán, C.P. 82010, A.P. 711, Sinaloa, México \\ ${ }^{2}$ Grupo Piscimar, Calle 41 No. 886, Nuevo Vedado, Plaza, La Habana, C.P. 10600, Cuba. alajonchere@gmail.com
}

\begin{abstract}
The spotted rose snapper, Lutjanus guttatus, is culture in several Latin American countries. The present study reports the generation closure with juveniles obtained from wild adults which matured and spawned at a Mazatlan laboratory (Mexico). F1 fish were sexually matured at 2 years of age, and spawning was induced in 2 successive years. F2 juveniles were reared until their sexual maturity and spawned at the same laboratory. Result indicate that a reliable supply of laboratory reared spawners can be achieved, avoiding the wild spawners dependence and allow the development of selection and genetic improve programs.
\end{abstract}

Key words: Lutjanidae, F1 broodstock maturation and spawning, generation closure

\section{INTRODUCTION}

The spotted rose snapper Lutjanus guttatus (Steindachner, 1869), is an important food and recreational species with high market prices of US\$ 5-8 kg-1 and strong demand in America (Avilés-Quevedo et al. 2008, BozaBarca et al. 2008). It is a batch spawner with asynchronous ovarian development and a long reproductive season (Cruz-Romero et al. 1996). During the last two decades, culture trials of the spotted rose snapper have been started in several Latin American countries along the Pacific Ocean (Avilés-Quevedo \& Mazón-Suástegui 1996, Avilés-Quevedo et al. 2008, Herrera-Ulloa et al. 2010). Their culture, however, is still mostly dependent on the collection of wild juveniles of various sizes (50-200 g), as has been reported in Mexico (Avilés-Quevedo et al. 2008, Alvarez-Lajonchère \& Puello-Cruz 2011), although artificially produced juveniles are reared in Costa Rica (Herrera-Ulloa et al. 2010). With limited, unpredictable and unstable supplies, this practice, especially with larger juveniles, can affect fishery recruitment from natural populations and result in conflicts between fishermen and aquaculturists.

Research projects on artificial reproduction techniques have been carried out in several countries mostly based on collecting mature wild fish (Ibarra-Castro \& Duncan 2007, Boza-Abarca et al. 2008, Ibarra-Castro \& Alvarez-
Lajonchère 2009). Recently spawning has been achieved with wild fish acclimatized and matured in captivity (Cano 2003, Boza-Abarca et al. 2008, Herrera-Ulloa et al. 2010, Ibarra-Castro \& Alvarez-Lajonchère 2011). However, in order to make aquaculture a sustainable activity, seed stock must be obtained from captive broodstock, as is the case with several other marine fish species (Moretti et al. 1999, Schipp et al. 2007). The overall goal is to control the entire life cycle of a given species from eggs to adults which can then mature and spawn in captivity in order to reproduce successive generations (Liao 1977). Controlling the life cycle is the only way of carrying out selection and genetic improvement programs, which would lead to a notable increase in aquaculture production, as found in agriculture and terrestrial livestock. The life cycle of the spotted rose snapper was closed in Panama (Cano 2003), although details of this study are limited.

This paper presents the results of the generation cycle closure of the spotted rose snapper, at the pilot-scale hatchery of the Research Centre for Food and Development (CIAD), at Mazatlan (Mexico), with data on their first sexual maturation and induced spawning results for 2 consecutive years. 


\section{Materials AND METHODS}

\section{ESTABLISHMENT AND SPAWNING OF F1 BROODSTOCK}

The establishment and spawning of a broodstock with wild adult spotted rose snappers and their successful spawning was described by Ibarra-Castro \& AlvarezLajonchère (2011). Briefly, a group of wild adults were caught at Sayulita Beach, Nayarit (Mexico), during May and June 2004 and transported to a pilot-scale hatchery at Mazatlan. Fish were reared in $18-\mathrm{m}^{3}$ fiberglass tanks supplied with seawater flow-through of 6 volumes day ${ }^{-1}$ and strong aeration. Fish were fed a mixture of oily fish flesh, squid and shrimp in equal proportions to satiation once a day for 6 days per week. In June 2005 the first wild broodstock fish reaching maturity in captivity with $0.80 \pm$ $0.13 \mathrm{~kg}$ body weight (BW, mean $\pm \mathrm{SD}$ ), were induced with $204 \pm 11 \mu \mathrm{g} \mathrm{kg}^{-1}$ GnRHa ([D-Ala6 Pro9 NEt]-GnRH) EVAc implants. After the hormone treatments were applied, each female with 2 males were placed in $3-\mathrm{m}^{3}$ spawning tanks with overflow egg collector baskets with 500- $\mu$ m mesh. The collectors were checked for the presence of eggs with a flashlight every hour, starting at $1800 \mathrm{~h}$.

Two natural spawns with high quality eggs (100\% live embryos, 12 h after fertilization) were obtained. Spawned eggs of wild captive broodstock used to obtain F1 juveniles had $90 \%$ viability (defined as percentage floating eggs with live embryos at 12-14 h after spawning) and a hatching rate of $82-93 \%$. Mean \pm SD egg and oil droplet diameters were $750 \pm 5 \mu \mathrm{m}$ and $122 \pm 2 \mu \mathrm{m}$, respectively. The incubation period at $35-36$ and $29-31^{\circ} \mathrm{C}$ ranged from 18-20 h. Newly hatched larvae had a total length (TL) of $2.2 \pm 0.2 \mathrm{~mm}$. Incubation and larval rearing was carried out in 600-L cylindrical tanks (initial stocked at 20 viable eggs $\mathrm{L}^{-1}$ ) from which several thousand juveniles were grown after 45-day experimental larviculture (Abdo de la Parra et al. 2010).

Nursery rearing of F1 hatchery produced juveniles was carried out in cylindrical fiberglass $5 \mathrm{~m}^{3}$ tanks, with a seawater flow of 4 volumes day $^{-1}$ and strong aeration. Lansy 1.2 mm (INVE Aquaculture, Mexico) artificial feed was supplied by hand ad libitum, four times day ${ }^{-1}$ for 15 days. Subsequently, a formulated pelleted shrimp diet (Alimentos de Occidente, S.A. de C.V., Mazatlan, Mexico) (40\% protein, $10 \%$ lipid) was supplied with two 12-h automatic feeders per tank. During the 6 months nursery stage, water temperature, salinity and dissolved oxygen varied between 22 and $29^{\circ} \mathrm{C}, 32$ to 35 , and 5.0 and $6.0 \mathrm{mg}$ $\mathrm{L}^{-1}$, respectively.
From January to September 2006, a group of 400 juveniles (30-40 g BW each) were selected for the establishment of a broodstock and stocked in four $7-\mathrm{m}^{3}$ fiberglass tanks $\left(0.5 \mathrm{~kg} \mathrm{~m}^{-3}\right)$ with a sea water flow rate of 4 volumes day $^{-1}$ and strong aeration. Fish were fed to satiation once daily, 6 days per week, with a diet of fresh squid and oily fish (mostly skipjack) in equal proportions. At the end of September 2006, 78 fish were selected from the F1 juvenile group, and stocked in equal numbers into two $7-\mathrm{m}^{3}$ fiberglass tanks, with a water flow to 6 volumes day $^{-1}$ using the same feeding practices described above. Juveniles were sampled several times during the nursery and grow-out period. In every sampling, 50 fish from each tank were anesthetized with 300 ppm of 2-phenoxiethanol (Sigma, Toluca, México) for morphological observations and determinations of TL to the nearest $\mathrm{mm}$, and body $\mathrm{BW}$ to the nearest g.

\section{F1INDUCED SPAWNING EXPERIMENTS}

On July 31, 2007 the TL and BW of F1 fish were determined, as well as their sexual development for their first induced spawning trial. Female gonad stage was assessed by a biopsy technique adapted to the rose spotted snapper, briefly described by Ibarra-Castro \& Alvarez-Lajonchère (2011). Sexual maturity of males was based on the presence and fluidity of milt determined by light abdominal pressure, and examination of sperm motility. F1 females with a mean oocyte diameter of at least $350 \mu \mathrm{m}$ and males with $\geq 80 \%$ motile spermatozoa were selected for the induced spawning experiments.

Selected fish were anesthetized with 300 ppm 2phenoxiethanol and tagged with $1.2 \mathrm{~cm}$ Passive Integrated Transponder (PIT) tags (Biomark, Idaho, USA) implanted into the dorsal muscle, for individual identification. Afterwards, selected females and males were implanted with GnRHa ([D-Ala6 Pro9 NEt]-GnRH) EVAc implant (Zohar \& Mylonas 2001), between 1000 and 1100 h. Each female was treated individually, according to its stage of sexual development (oocyte mean diameter) and BW. All males received an implant dose of approximately $75 \mu \mathrm{g}$ $\mathrm{kg}^{-1}$. The effective doses of GnRHa were estimated based on an induced spawning protocol developed for captive fish of this species (Ibarra-Castro \& Alvarez-Lajonchère 2009). After spawning, the fish returned to their $7-\mathrm{m}^{3}$ fiberglass tanks and left undisturbed for one year under the same rearing conditions described above.

In June 2008 the F1 broodstock fish were again sampled, for TL and BW determinations, as well as their 
sexual development, and 3 females and 6 males were selected for a second induce spawning trial.

\section{STATISTICAL ANALYSIS}

Results are expressed as means \pm standard error of the mean (SEM), unless otherwise indicated. All percentage data were normalized by arcsin square transformation prior to statistical analyses. Homogeneity of variances and testing for normality were conducted. Parametric data were subjected to one-way analysis of variance (ANOVA) and when significant, a multiple comparison test (Tukey) was applied. Non parametric data were analyzed using a Kruskal-Wallis ANOVA test, and when significant, the multiple comparisons Dunn's test was performed. Differences were considered significant at $P<0.05$ unless otherwise indicated. The data were analyzed using SigmaStat 3.1 (SYSTAT Software, Inc., Point Richmond, California, USA) statistical software package.

\section{Results AND DISCUSSION}

F1 juveniles 45 days post-hatch (dph) produced in 600-L larval rearing tanks had a TL of $4.5 \pm 0.3 \mathrm{~cm}$ and a BW of $0.5 \pm 0.3$ g. They grew to $30.5 \mathrm{~cm}$ TL $\left(y=9.9131 \mathrm{e}^{0.0015 x}, \mathrm{R}^{2}\right.$ $=0.957)$ and $583 \mathrm{~g} \mathrm{BW}\left(\mathrm{y}=12.183 \mathrm{e}^{0.0052 \mathrm{x}}, \mathrm{R}^{2}=0.959\right)$ in 25 months (Fig. 1), in $5-\mathrm{m}^{3}$ and later $7-\mathrm{m}^{3}$ tanks, when the sexual development was considered adequate for induced spawning.

The laboratory tank growth of artificially produced juveniles was slow compared to the growth of commercially reared wild juveniles in floating cages (Avilés-Quevedo et al. 2008) as well as significantly slower $(P<0.05)$ than siblings of this progeny reared in floating cages with similar temperature and salinity conditions (Abdo de la Parra et al. 2011). The water quality and flow rate, in addition to the vital space effect of being reared in small tanks could have been the cause of slower growth in the laboratory. In Costa Rica, growth of wild spotted rose snapper has been reported faster than in Mexico, and sexual maturity is attained at a similar size, but at 2 years of age (Rojas 1997) as in the captive F1 fish at the present study, instead of the 4 years required for fish in Mexico (Amezcua et al. 2006). Also, captive fish growth is faster in Costa Rica (Boza-Abarca et al. 2008) compared to those reared in Mexico (Avilés-Quevedo et al. 2008). This suggests that there may be growth differences between the populations, as in the case of other the striped mullet, Mugil cephalus (Tamaru et al. 1993).

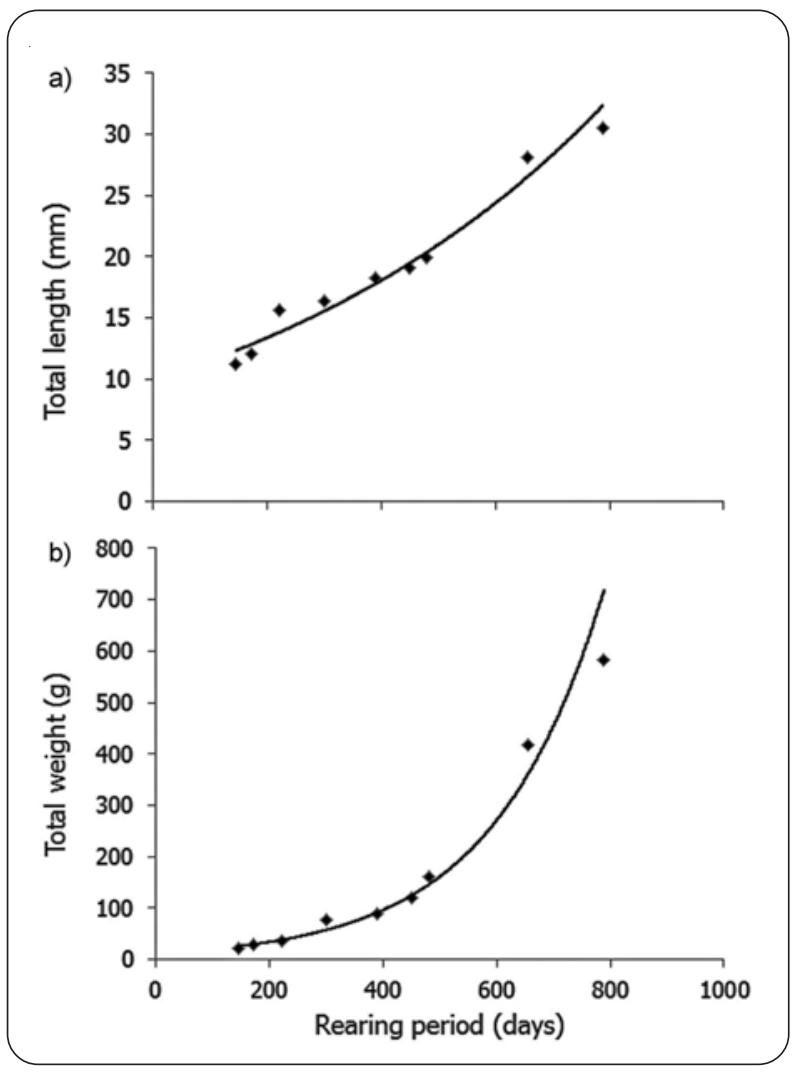

Figure 1. Growth of F1 juveniles before induced spawning experiments: a) total length; b) total weight / Crecimiento de los juveniles $\mathrm{F} 1$ antes de los experimentos de inducción del desove: a) largo total; b) peso total

On July 31 2007, 5 females (BW = $687 \pm 74$ g; TL = 32.0 $\pm 1.6 \mathrm{~cm}$ ) with a mean oocyte diameter of $360 \pm 19 \mu \mathrm{m}$ were induced with a mean GnRHa EVAc implant dose of $239 \pm$ $20 \mu \mathrm{g} \mathrm{kg}^{-1}$. All males had sperm with $>80 \%$ motility, and 10 were selected $(\mathrm{BW}=553 \pm 82 \mathrm{~g}$; $\mathrm{TL}=30.0 \pm 1.6 \mathrm{~cm}$ ) and implanted with a mean dose of $72 \pm 26 \mu \mathrm{g} \mathrm{kg}^{-1} \mathrm{GnRHa}$. During the second night, 2 females spawned (36 and $43 \mathrm{~h}$ after hormone-treatment), but few floating eggs were collected (90\% viable eggs) (Table 1). Mean egg and lipid droplet diameters were $739 \pm 17 \mu \mathrm{m}$ and $117 \pm 12 \mu \mathrm{m}$, respectively. These eggs had $66 \%$ hatching (Table 1 ).

The next year in June 2008, 3 females (BW $=687 \pm 9 \mathrm{~g}$; $\mathrm{TL}=32.0 \pm 0.2 \mathrm{~cm})$ and six males $(\mathrm{BW}=745 \pm 121 \mathrm{~g}$; $\mathrm{TL}=$ $35.7 \pm 2.8 \mathrm{~cm}$ ) were selected for a second induced spawning trial. Females had a mean oocyte diameter of $410 \pm 20 \mu \mathrm{m}$ and received a GnRHa dose of $188 \pm 55 \mu \mathrm{g} \mathrm{kg}^{-1}$ while males received a mean implant dose of $70 \pm 12 \mu \mathrm{g} \mathrm{kg}^{-1}$. Two of the three females had multiple spawns (Table 1). One fish initially released a few eggs with a low percent 
Table 1. Induced spawning results of F1 broodstock in July 2007 and June 2008 / Resultados de la inducción del desove de los reproductores F1 en julio de 2007 y junio de 2008

\begin{tabular}{|c|c|c|c|c|c|c|c|c|c|c|c|}
\hline \multirow[t]{2}{*}{ Date } & \multirow[t]{2}{*}{ Female } & \multirow{2}{*}{$\begin{array}{l}\mathrm{TL} \\
(\mathrm{cm})\end{array}$} & \multirow{2}{*}{$\begin{array}{l}\text { BW } \\
(\mathrm{g})\end{array}$} & \multirow{2}{*}{$\begin{array}{c}\text { Initial oocyte } \\
\text { diameter }(\mu \mathrm{m})\end{array}$} & \multirow{2}{*}{$\begin{array}{c}\text { Dose } \\
\left(\mu \mathrm{g} \mathrm{kg}^{-1}\right)\end{array}$} & \multirow{2}{*}{$\begin{array}{l}\text { Latency } \\
\text { (h) }\end{array}$} & \multirow{2}{*}{$\begin{array}{c}\text { Total } \\
\text { fecundity }\end{array}$} & \multirow{2}{*}{$\begin{array}{c}\text { Floating } \\
\text { eggs }\end{array}$} & \multirow{2}{*}{$\begin{array}{l}\text { Viability (\%) / } \\
\text { Hatching (\%) }\end{array}$} & \multicolumn{2}{|c|}{ Mean diameter $\pm \operatorname{SEM}^{a}(\mu \mathrm{m})$} \\
\hline & & & & & & & & & & Egg & Oil droplet \\
\hline July 31, 2007 & 1 & 30.5 & 628 & $388 \pm 22$ & 239 & 36 & 81,851 & 2,640 & $90 / 66$ & $751 \pm 17$ & $125 \pm 11$ \\
\hline July 31, 2007 & 2 & 30.5 & 642 & $347 \pm 17$ & 234 & - & - & -- & 0 & - & - \\
\hline July 31, 2007 & 3 & 34.8 & 830 & $355 \pm 21$ & 271 & 43 & 55,582 & - & 0 & $727 \pm 18$ & $108 \pm 12$ \\
\hline July 31,2007 & 4 & 31.5 & 646 & $341 \pm 17$ & 232 & - & - & -- & 0 & -- & - \\
\hline July 31,2007 & 5 & 32.5 & 688 & $371 \pm 18$ & 218 & - & -- & - & 0 & - & - \\
\hline June 28,2008 & 1 & 36.5 & 876 & $325 \pm 21$ & 228 & - & - & - & & & - \\
\hline June 28,2008 & 2 & 45.1 & 1308 & $400 \pm 22$ & 156 & 63 & 20,300 & 3,400 & 0 & $711 \pm 5$ & $93 \pm 3$ \\
\hline June 29, 2008 & & & & & & - & 88,000 & 14,700 & 0 & $735 \pm 3$ & $87 \pm 4$ \\
\hline June 27, 2008 & 3 & 47.2 & 1496 & $400 \pm 20$ & 181 & 39 & 80,000 & 6,000 & $1 /-$ & $717 \pm 4$ & $122 \pm 3$ \\
\hline June 28,2008 & & & & & & - & 296,000 & 148,000 & $89 / 75$ & $734 \pm 5$ & $91 \pm 2$ \\
\hline June 29, 2008 & & & & & & - & 43,000 & 36,000 & $90 / 86$ & $765 \pm 4$ & $125 \pm 1$ \\
\hline June 30,2008 & & & & & & - & 127,000 & 125,000 & $70 / 71$ & $759 \pm 4$ & $93 \pm 2$ \\
\hline July 1,2008 & & & & & & - & 353,000 & 353,000 & $98 / 90$ & $682 \pm 8$ & $125 \pm 1$ \\
\hline July 2,2008 & & & & & & -- & 202,000 & 202,000 & $97 / 86$ & $726 \pm 5$ & $125 \pm 4$ \\
\hline
\end{tabular}

${ }^{a}=$ Standard error of the mean

viability $39 \mathrm{~h}$ after the hormone treatment and then continued for another 5 consecutive nights, spawning a mean of $172,800 \pm 121$ eggs with high viability of $81.6 \pm$ $8.4 \%$. The other female spawned during the third and fourth night after the hormone treatment and none of the eggs were fertilized. Diameter of egg and high viability percentage were $725 \pm 5 \mu \mathrm{m}$ and $80.4 \pm 10 \%$ of buoyant eggs (Table 1). F2 juveniles from these spawns were reared in the same hatchery to maturity with the same methods described above, and were spawned with 2 years of age, following the same procedures (Ibarra-Castro et al. unpublished).

Although the spawning results from first sexual maturation of the hatchery-born broodstock showed poor results, the larvae produced a progeny that was able to grow and mature in captivity. The results of the second spawning experiment with three-year adults were significantly more productive than in the first experiment $(P<0.05)$, as found in other species (Carrillo et al. 2000) and were not significantly different $(P>0.05)$ from those previously reported for captive wild broodstock spotted rose snapper in terms of fecundity, viability, and egg and lipid diameter characteristics (Ibarra-Castro \& AlvarezLajonchère 2011). Survival rate achieved was satisfactory, compared to other marine fish hatcheries (Moretti et al. 1999) agreeing with other reports (Schipp et al. 2007).

Results of the present study indicate that broodstock should initially be reared from hatchery produced juveniles to adult size in floating cages, for maximizing growth rates.
The successful sexual maturation and spawning of the spotted rose snapper F1 fish indicates that controlled reproduction of the complete generation cycle in captivity can be achieved. These procedures could be used with broodstock fish for mass production of juveniles, allowing the extension of culture technology to a commercial scale without depending on wild fish.

\section{ACKNOWLeDgments}

Authors are grateful to their colleagues at the CIAD Reproduction Laboratory, for their cooperation, and to several colleagues for their useful comments and recommendations. Our thanks are expressed to M. Ribas, for English and editorial improvements to the manuscript. This study was supported by project grants $6299-\mathrm{K}$ and 6299-A from the National Aquaculture and Fishery Commission (CONAPESCA) and Mazatlan Unit of CIAD administration fund.

\section{LITERATURE CITED}

Abdo-de la Parra MI, LE Rodríguez-Ibarra, F CampilloMartínez, G Velasco-Blanco, N García-Aguilar, L Alvarez-Lajonchère \& D Voltolina. 2010. Efecto de la densidad de siembra sobre el crecimiento y supervivencia larval del pargo lunarejo Lutjanus guttatus. Revista de Biología Marina y Oceanografía 45: 141-146.

Abdo-de la Parra MI, GAldana-Flores, LE Rodríguez-Ibarra, G Velasco-Blanco, N García Aguilar, L AlvarezLajonchère, EG Cabral-Solis, PE Pérez Velásque \& AR Colin-Monreal. 2011. Transporte y engorda de 
juveniles de laboratorio de pargo flamenco (Lutjanus guttatus) en jaulas flotantes en la costa de Colima. Industria Acuícola 7: 4-8.

Alvarez-Lajonchère L \& AC Puello-Cruz. 2011. El pargo flamenco: Lutjanus guttatus. Producción controlada de huevos, larvas y juveniles, 169 pp. Clave editorial, México.

Amezcua F, C Soto-Avila \& Y Green-Ruiz. 2006. Age, growth, and mortality of the spotted rose snapper Lutjanus guttatus from the Gulf of California. Fisheries Research 77: 293-300.

Avilés-Quevedo A \& JM Mazón-Suástegui. 1996. Cultivo de peces marinos. En: Casas-Valdez M \& G Ponce-Díaz (eds). Estudio del potencial pesquero y acuícola de Baja California Sur, pp. 651-684. SEMARNAP, La Paz.

Avilés-Quevedo A, JM Mazón-Suástegui \& F CastellóOrvay. 2008. Avances en el cultivo del pargo flamenco, Lutjanus guttatus, un ejemplo a seguir de los pescadores de Bahía Concepción, en Baja California Sur. Industria Acuícola 4: 4-7.

Boza-Barca J, E Calvo-Vargas, N Solis-Ortiz \& J Komen. 2008. Induced spawning and larval rearing of spotted rose snapper, Lutjanus guttatus, at the Marine Biology Station, Puntarenas, Costa Rica. Ciencias Marinas 34: 239-252.

Cano A. 2003. Reproduction in captivity and cultivation of the Pacific rose spotted snapper Lutjanus guttatus in the Republic of Panama, 153 pp. World Aquaculture Society Conference, Salvador de Bahia.

Carrillo M, S Zanuy, F Oyen, J Cerdá, JM Navas \& J Ramos. 2000. Some criteria of the quality of the progeny as indicators of physiological broodstock fitness. In: Recent advances in Mediterranean aquaculture finfish species diversification. Proceedings of the Seminar of the CIHEAM Network on technology of aquaculture in the Mediterranean (TECAM), jointly organized by CIHEAM and FAO, Zaragoza (España), 24-28 mayo de 1999. Cahiers Options Mediterranées 47: 61-74.

Cruz-Romero M, EA Chavez, E Espino \& A Garcia. 1996. Assessment of a snapper complex (Lutjanus spp.) of the eastern tropical Pacific. In: Arregüin-Sánchez F, JL Munro, MC Balgos \& D Pauly (eds). Biology and culture of tropical groupers and snappers. ICLARM Conference Proceedings 48: 331-337.
Herrera-Ulloa A, J Chacón-Guzmán, G Zúñiga-Calero \& R Jiménez-Montealegre. 2010. Spotted rose snapper (Lutjanus guttatus) aquaculture research and development as socio-economic alternative for Costa Rican fisheries communities. World Aquaculture 41: 20-22.

Ibarra-Castro L \& LAlvarez-Lajonchère. 2009. An improved induced-spawning protocol for spotted rose snapper Lutjanus guttatus. The Israeli Journal of AquacultureBamidgeh 61: 121-133.

Ibarra-Castro L \& L Alvarez-Lajonchère. 2011. GnRHa induced multiple spawns and volition spawning of captive spotted rose snapper, Lutjanus guttatus, at Mazatlan, Mexico. Journal of the World Aquaculture Society 42: 564574.

Ibarra-Castro L \& NJ Duncan. 2007. GnRHa-induced spawning of wild-caught spotted rose snapper Lutjanus guttatus. Aquaculture 272: 737-746.

Liao I-C. 1977. On completing a generation cycle of the grey mullet, Mugil cephalus, in captivity. Journal of the Fisheries Society of Taiwan 5: 1-10.

Moretti A, M Pedini Fernandez-Criado, G Cittolin \& R Guidastri. 1999. Manual on hatchery production of seabass and gilthead seabream 1: 1-194. FAO, Rome.

Rojas R. 1997. Fecundidad y épocas de reproducción del pargo mancha Lutjanus guttatus (Pisces: Lutjanidae) en el Golfo de Nicoya, Costa Rica. Revista de Biología Tropical 44: 477-487.

Schipp G, J Bosmans \& J Humphrey. 2007. Barramundi farming handbook, 80 pp. Department of Primary Industry, Fisheries and Mines, Northern Territory Government, Darwin.

Tamaru CS, WJ FitzGerald \& V Sato. 1993. Hatchery manual for the artificial propagation of striped mullet (Mugil cephalus L.), 167 pp. Guam Aquaculture Development and Training Center and the Oceanic Institute, Tamuning.

Zohar Y\& CC Mylonas. 2001. Endocrine manipulations of spawning in cultured fish: from hormones to genes. Aquaculture 197: 99-136.

Received 4 March 2012 and accepted 29 May 2012

Associate Editor: Mauricio Landaeta D. 